\title{
The nutritional ecology of larvae of $A$ lsophila pometaria and $A$ nisota senatoria feeding on early- and late-season oak foliage
}

\author{
D. L. Lawson ${ }^{1}$, R. W. Merritt', M. M. Martin², J. S. Martin² \& J. J. Kukor ${ }^{2}$ \\ 'Department of Entomology, Michigan State University, East Lansing, MI 48824: ${ }^{2}$ Division of Biological \\ Sciences, University of Michigan, Ann Arbor, MI 48109. USA
}

Keywords: Alsophila pometaria, Geometridae, Anisota senatoria, Citheronidae, Quercus, nutritional ecology, herbivory, nutritional indices, consumption, growth, utilization efficiency, nitrogen, water, tannins, phenols, gut $\mathrm{pH}$, digestive enzymes

\begin{abstract}
The larvae of Alsophila pometaria (Harr.), feeding on the young foliage of oak, has a higher relative growth rate (RGR) and relative nitrogen accumulation rate (RNAR) than the larvae of Anisota senatoria (J. E. Smith), feeding on the mature foliage of oak. Although the young oak foliage is more efficiently digested by $A$. pometaria (higher AD's), it is not more efficiently assimilated and used for growth (no difference in ECI's). Thus, the higher growth rate of $A$. pometaria is due entirely to a higher consumption rate (RCR and RNCR). Young foliage is significantly higher in nitrogen and water than mature foliage, but phenol and tannin levels are comparable in young and old foliage. A. pometaria consumes the foliage of different oak species at the same rate, independent of nitrogen content, while $A$. senatoria increases its consumption rate in response to decreased nitrogen levels. As a result, the growth rate of $A$. pometaria is directly related to leaf nitrogen content, while the growth rate of A. senatoria is independent of leaf nitrogen. The two species of insects have digestive systems that are very similar biochemically, and that are well-designed for effective protein digestion. Tannins and phenols do not influence the nutritional indices of either species. We suggest that the major benefit of spring feeding is the availability of succulent, high-nitrogen foliage, and not the avoidance of high-tannin foliage. The spring feeder appears to have a feeding strategy that favors rapid growth at the expense of efficiency, while the late summer feeder has a strategy that favors efficiency over rate.
\end{abstract}

\section{Introduction}

The nutritive quality of tree foliage is generally considered to decline as the growing season progresses. Nitrogen and water content exhibit progressive seasonal decreases, while physical toughness increases (Rausher, 1981; Scriber \& Slansky, 1981; Schultz et al., 1982). Tannins and other polyphenols, substances known to be toxic to some herbivores, are present in higher amounts in the mature foliage of some tree species (Feeny, 1970; Haukioja et al. 1978), and in the young foliage of others (Fox \& Macauley, 1977; Gartlan et at., 1980; Oates et al., 1980; Becker \& Martin, 1982; Schultz et al., 1982). The higher nutritive quality of young foliage compared to mature foliage is generally presumed to underly the greater susceptibility of young foliage to herbivory (Haukioja et al., 1978; Coley, 1980; Rausher, 1981), and the reduced growth and survival observed in an number of species when they are fed the mature foliage of their host plant rather than the young foliage (Feeny, 1968, 1970; Mansingh, 1972; Hough \& Pimentel, 1978; Mitter et al., 1979; Schweitzer, 1979; Haukioja et al., 1978; Coley, 1980; Rausher, 1981).

In this study, the nutritional ecology of Alsophila pometaria, a geometrid caterpillar that feeds on early-season oak foliage, has been compared to that of Anisota senatoria, a citheroniid caterpillar that feeds on late-season oak foliage. The nutritional 
indices of A. pometaria were determined on early season foliage of white oak (Quercus alha L.), swamp white oak ( $Q$. bicolor Willd, ), bur oak ( $Q$. macrocarpa Minchx.), red oak ( $Q$. rubra L.) and black oak ( $Q$. velutina Lami.), while those of $A$. senatoria were determined on late-season foliage of the same five species of oak, plus pin oak (Q.palustris Huenchh.). The nutritive quality of the foliage samples was assessed by measuring nitrogen, water, phenol, proanthocyanidin, and tannin content, while the characteristics of the digestive systems of the two insect species were compared by measuring the gut pH's and the enzymatic activities of the caterpillars" gut fluids toward Azocoll (a general substrate for proteinases) and a variety of polysaccharides.

\section{Materials and methods}

\section{Chemical studies}

Phenols and proanthocyanidins. Early season foliage was collected on May 27, 1980, while late season foliage was collected on Sept. 10, 1979. After removal of the midrib, foliage was lyophilized and ground to particle size $250 \mu \mathrm{m}$ using a Wiley mill. Ground leaf powder was stored in a desiccator until analysis (four months for young foliage, seven months for mature foliage). Although some deterioration is inevitable during periods of storage of this duration even when the samples are in a lyophilized state, the limited changes that occur do not compromise comparisons of foliage, since parallel and roughly comparable changes occur in all sam-. ples (Gartlan et al., 1980; Martin \& Martin, 1982). Between 6 and $12 \mathrm{mg}$ of lyophilized leaf powder was extracted with $50 \%$ methanol $(3 \mathrm{ml}$ per $\mathrm{mg}$ leaf powder) for $10 \mathrm{~min}$ at $80^{\circ} \mathrm{C}$. Following centrifugation $\left(12000 \times \mathrm{g}, 5^{\circ} \mathrm{C}, 20 \mathrm{~min}\right)$, the supernatant solution was collected and its volume accurately determined. Aliquots of this extract were used in the phenol and proanthocyanidin assays. Total phenols were measured using the Folin-Denis procedure (Swain \& Hillis, 1959; Ribèreau-Gayon, 1972). Proanthocyanidins were assayed using the method of Hillis and Swain (1959) with an $80 \%$ butanol-hyd rochloric acid reagent containing $15.4 \%$ (w/v) ferrous sulfate (Govandarajan \& Mathew, 1965).
Protein-precipilating capacity (tannin content). Approximately $60 \mathrm{mg}$ of leaf powder, prepared as described above, was extracted twice with $4 \mathrm{ml}$ of boiling $50 \%$ methanol for seven min. Following the last centrifugation $\left(12000 \times \mathrm{g}, 5^{\circ} \mathrm{C}, 15 \mathrm{~min}\right)$, the pellet was washed with about $1 \mathrm{ml}$ of $50 \%$ methanol, and the mixture was centrifuged as above. The combined supernatant solutions were diluted to a final volume of $10.0 \mathrm{ml}$ with $50 \%$ methanol. Aliquats of this solution, corresponding to extract derived from 0.69 to $4.14 \mathrm{mg}$ of leaf powder, were assayed for protein-binding capacity using the BSA-precipitation procedure of Martin \& Martin (1982). Measurements were performed at five different extract concentrations on at least two separate extracts, and regression coefficients (slopes) and $y$-intercepts were calculated according to Sokal \& Rohlf (1969). In calculating standard errors of the regression coefficients, mean squares were not pooled, so that $\mathrm{df}=3$. The significance of differences between regression coefficients was tested at the level, $\mathbf{P}<0.01$, using the Simultaneous Test Procedure of Sokal \& Rohlf (1969).

Total nitrogen. Nitrogen content (on a dry weight basis) was determined for foliage samples and larvae using a model 1 102 Carlo-Erba elemental analyzer.

\section{Studies on gut fluids}

$p H$ measurements. Measurements of $p H$ were made on intact guts, exposed along most of their length while still in the insect, by folding back adjacent tissues and inserting a combination $\mathrm{pH}$ microelectrode (BioRad 163-2013) in the midgut in anterior, medial, and posterior locations. Measurements were made in reverse sequences (anterior to posterior versus posterior to anterior) on successive midguts. No mixing of the contents was evident during these manipulations.

Enzyme assays. Midguts from live fourth instar $A$. pometaria and fifth instar $A$. senatoria were dissected under distilled water. Gut segments from 4 to 10 individuals, with contents intact, were homogenized by hand in a tissue homogenizer in a volume of cold water equal to about ten times the tissue volume. Following centrifugation $\left(10000 \times \mathrm{g}, 4^{\circ} \mathrm{C}\right.$, $20 \mathrm{~min}$ ), the supernatant solution was collected and 
the pellet resuspended in a volume of water equal to that of the original extract. Following centrifugation, the supernatant solutions were combined and made up to a total volume which was an integral multiple of $2.5 \mathrm{ml}$. Then $2.5-\mathrm{ml}$ aliquots were placed on Sephadex G- $25 \mathrm{M}(1.2 \times 5.0 \mathrm{~cm}$, Pharmacia PD-10 columns), and proteins were eluted in 3.5 $\mathrm{ml}$ of water.

Proteolytic activity was assayed using Azocoll (Calbiochem, 19493) as the substrate (Martin et al., $198 \mathrm{lb}$ ). Activities toward microcrystalline cellulose (Polyscience 4853), potato amylose (Calbiochem 172681), carboxymethylcellulose (Sigma C-8758), laminarin (Calbiochem 428001), larchwood xylan (Sigma X-3875), locust bean gum (Sigma G-0753) and citrus pectin (Sigma P-9135) were assayed by measuring the rate of liberation of reducing groups (maltose equivalents) using the 3,5-dinitrosalicylic acid reagent (Bernfeld, 1955), as adapted by Martin et al. (1981a). Controls in all of the above enzyme assays were run using aliquots of extract inactivated by heating. The buffers used were $0.1 \mathrm{M}$ sodium acetate ( $\mathrm{pH} 5.1,5.6), 0.1 \mathrm{M}$ sodium phosphate $(\mathrm{pH}$ 6.0, 7.0, 7.5, 11.5, 12.0, 12.5), $0.1 M$ Tris (pH 8.0, $8.5,9.0$ ), and $0.1 \mathrm{M}$ sodium carbonate ( $\mathrm{pH} 9.5,10.0$, $10.5,11.0$ ).

\section{Nutritional indices}

Eggs of the fall cankerworm, A. pometaria, and second instars of the orange striped oakworm, $A$. senatoria, were collected form the field on May 6, 1980 and August 30, 1979, respectively, and reared at $24^{\circ} \mathrm{C}$ under seasonal photoperiods. Larvae were fed red oak until the penultimate larval instar, at which time the larvae were divided randomly into six groups and fed one of six species of oak foliage. A. pometaria larvae were fed the same species of oak, excluding pin oak. Ten freshly molted fourth instar A. pometaria and 20 freshly molted fifth instar $A$. senatoria larvae from each leaf species were transferred individually to $0.47-1$ waxed-papcr cups with a hole punched in the battom. The petiole of a freshly harvested leaf was placed through the hole and the cup placed within another cup filled with $20 \mathrm{ml}$ distilled water to provide a continuous water supply to the leaf. Larval and leaf fresh weights were determined and then converted to dry weights (Waldbauer, 1968). Fresh leaves were added and feces removed at 24-h intervals.
The following nutritional indices were calculated on a dry weight basis using the procedures of Waldbauer (1968). Mean larval biomass is defined as the average of the sum of the initial and final dry weights of the larvae.

Relative Consumption Rate:

$\mathrm{RCR}(\mathrm{mg} / \mathrm{mg} /$ day $)=$ food ingested per unit mean larval biomass per day

Relative Growth Rate:

$\mathrm{RGR}$ ( $\mathrm{mg} / \mathrm{mg} /$ day) = biomass gained per unit mean larval biomass per day $=(\mathrm{RCR})$ (ECI) $/ 100$

Approximate Digestibility: $\operatorname{AD}(\%)=100$ (food ingested feces) $/$ food ingested.

Efficiency of Conversion of Digested Fond $\operatorname{ECD}(\%)=100$ (biomass gained) $/($ food ingested - feces).

Efficiency of Conversion of Ingested Food: ECl $(\%)=100$ (biomass gained) $/$ food ingested $=(A D)(E C D) / 100$.

Relative Nitrogen Consumption Rate: RNCR $(\mu \mathrm{g} / \mathrm{mg} /$ day $)=$ biomass nitrogen ingested per unit mean larval biomass per day.

Relative Nitrogen Accumulation Rate; RNAR $(\mu \mathrm{g} / \mathrm{mg} /$ day $)=$ biomass nitrogen gained per unit mean larval biomass per day. Nitrogen Utilization Efficiency:

NUE $(\%)=100$ (biomass nitrogen gained) nitrogen ingested.

A Pearson Correlation procedure related the above indices to concentrations of leaf nitrogen, total phenol, proanthocyandin and BSA-precipitating capacity. Mean differences were derived from standard ANOVA procedures and a posterio$r i$ contrasts (Sokal \& Rohlf, 1969).

\section{Results}

\section{Chemical characteristics of foliage}

The nitrogen content of the young oak foliage collected on May 27 th is higher than the nitrogen content of the mature foliage collected September 10th (Table 1). The Folin-Denis assay showed that spring and autumn foliage had roughly comparable levels of total phenols except in bur and black oak, in which the young foliage had higher concentra- 
Table 1. Chemical characteristics of early- and late-season oak foliage. Walues are $\overline{\mathbf{X}} \pm \mathbf{S E}$ (n.d. = not determined). An asterisk following the value for early-season foliage indicates that early-and late-season foliage values differ significantly $(\mathrm{p}<0.05)$. Data for late-season foliage is from Lawson et al. (1982).

\begin{tabular}{|c|c|c|c|c|c|}
\hline & $\begin{array}{l}\text { Nitrogen } \\
(\%)\end{array}$ & $\begin{array}{l}\text { Water } \\
(\%)\end{array}$ & $\begin{array}{l}\text { Total phenols } \\
\left(A_{725} / \text { mg dry } w t\right)\end{array}$ & $\begin{array}{l}\text { Proanthocyanidins } \\
\left(A_{550} / \mathrm{mg} d r y \text { w }\right)\end{array}$ & $\begin{array}{l}\text { BSA-precipitation } \\
\text { (mg pptd/mg dry wt) }\end{array}$ \\
\hline \multicolumn{6}{|c|}{ White oak } \\
\hline Early & $3.03 \pm 0.06^{*}$ & $70.2 \pm 0.3^{*}$ & $3.537+0.143$ & $0.005 \pm 0.00 I^{*}$ & $0.15 \pm 0.01$ \\
\hline Late & $2.26 \pm 0.11$ & $51.5 \pm 0.8$ & $3.422 \pm 0.029$ & $0.070 \pm 0.001$ & $0.09 \pm 0.01$ \\
\hline \multicolumn{6}{|c|}{ Swamp-white oak } \\
\hline Early & $3.61=0.09 *$ & $72.6 \pm 0.2^{*}$ & n.d. & n.d. & ı1,d. \\
\hline Late & $2.82 \pm 0.09$ & $45.9 \pm 0.9$ & $2.412 \pm 0.032$ & $0.442 \pm 0.004$ & $0.18 \pm 0.01$ \\
\hline \multicolumn{6}{|l|}{ Bur oak } \\
\hline Early & $3.39 \pm 0.06^{*}$ & $69.3 \pm 0.3 *$ & $3.572 \pm 0.022^{*}$ & $0.051 \pm 0.003^{*}$ & $0.21 \pm 0.02$ \\
\hline Late & $2.92+0.12$ & $48.4 \pm 0.5$ & $3.158 \pm 0.026$ & $0.340 \pm 0.004$ & $0.28 \pm 0.02$ \\
\hline \multicolumn{6}{|l|}{ Pin oak } \\
\hline Early & $2.51 \pm 0.02^{*}$ & $69.8 \pm 0.4^{*}$ & $3.333 \pm 0.209$ & $0.036 \pm 0.003^{*}$ & $0.45 \pm 0.03$ \\
\hline Late & $2.27 \pm 0.10$ & $54.6 \pm 0.6$ & $3.164 \pm 0.015$ & $0.167 \pm 0.002$ & $0.33 \pm 0.01$ \\
\hline \multicolumn{6}{|l|}{ Red oak } \\
\hline Early & $2.85 \pm 0.02^{*}$ & $69.0 \pm 0.3^{*}$ & $1.676 \pm 0.010$ & $0.046 \pm 0.003 *$ & $0.15 \pm 0.01$ \\
\hline Late & $2.22 \pm 0.09$ & $52.2 \pm 0.2$ & $1.894 \pm 0.079$ & $0.235 \pm 0.003$ & $0.14 \pm 0.01$ \\
\hline \multicolumn{6}{|c|}{ Black oak } \\
\hline Early & $2.86=0.02^{*}$ & $67.6 \pm 0.2^{*}$ & $4.399 \pm 0.088^{*}$ & $0.007 \pm 0.00 \mathrm{I}^{*}$ & $0.27 \pm 0.02^{*}$ \\
\hline Late & $2.11 \pm 0.09$ & $52.0 \pm 0.8$ & $2.683 \pm 0.089$ & $0.128 \pm 0.003$ & $0.11 \pm 0.01$ \\
\hline
\end{tabular}

tions. By contrast, proanthocyanidins are higher in the mature foliage, possibly suggesting a seasonal accumulation of condensed tannins. However, total tannins, or more precisely the total capacity of foliage constituents to precipitate protein, is no higher in mature foliage than in young foliage. These findings add one more example to a growing list of plant species in which young leaves have tannin and phenol levels at least as high as those of the mature leaves, and suggest that the early season foliage is as well protected by allelochemicals as the foliage produced later in the season. In an earlier study, Lawson et al. (1982) demonstrated that the mature leaves of these oak species contained between $46 \%$ and $52 \%$ water, while the young foliage used in this study had water contents that fell in the range of $67-73 \%$, values comparable to those reported in the review by Scriber \& Slansky (1981) for mature and young tree foliage.

\section{Characteristics of the caterpillars' gut fluids}

Highly alkaline conditions prevail throughout the entire lengths of the midguts of both species (Table 2). The proteolytic enzymes of both species are clearly adapted to function under basic conditions, since activity is quite high over the $\mathrm{pH}$ range 9.5-11.5, exhibiting a maximum at $\mathrm{pH} 10.5$ (Fig. 1). The level of proteolytic activity toward Azocoll at $\mathrm{pH} 10.5$ is very high in the midgut fluids of both species (Table 3). The unpurified midgut contents actually possess activity within an order of magnitude of that of some commercial preparations of partially purified proteolytic enzymes. One milli-

Table 2. $\mathrm{pH}$ in anterior medial and posterıor sections of the midguts of larvae of $A$. pomelaria (4th instar) and $A$. senatoria (Sth instar). Values are $\chi+S E$, with the range and number of determinations given in parenthesis.

\begin{tabular}{|c|c|c|}
\hline \multirow{2}{*}{$\begin{array}{l}\text { Location } \\
\text { in midgut }\end{array}$} & \multicolumn{2}{|l|}{$\mathbf{p H}$} \\
\hline & A. pometaria & A. senatoria \\
\hline Anterior & $9.7 \pm 0.2(8.9-10.0,6)$ & $9.9 \pm 0.2(9-2-10.5,4)$ \\
\hline Medial & $9.4 \pm 0.3(8.4-10.3,6)$ & $10.0 \pm 0.2(9.3-10.7,5)$ \\
\hline Posterior & $9.0 \pm 0.2(8.2 \quad 9.6,6)$ & $9.5 \pm 0.5(7.6 \cdots 10.2,5)$ \\
\hline
\end{tabular}




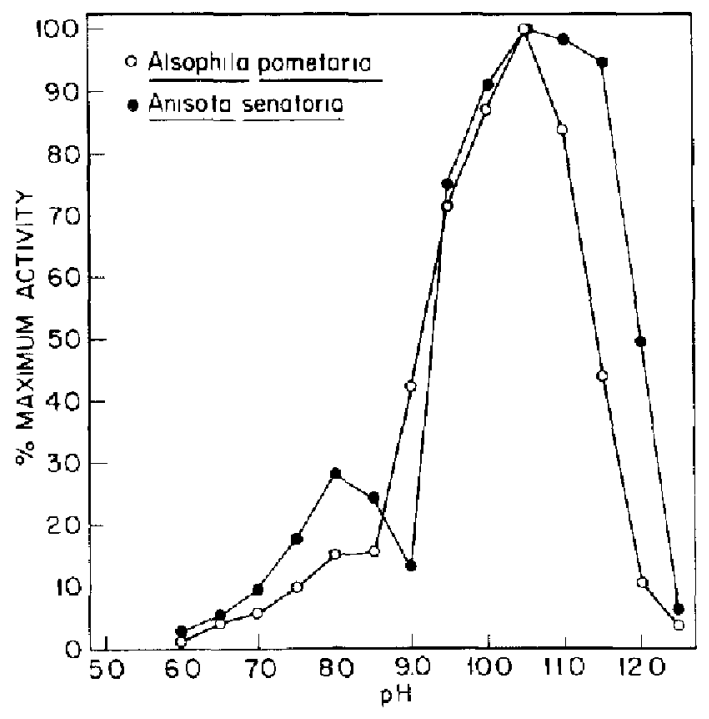

Fig. I Dependence of midgut proteolytıc activity on $\mathrm{pH}$.

gram (dry weight) of the midgut homogenates from both species, assayed at $\mathrm{pH} 10.5$, possesses activity toward Azocoll equivalent to nearly $0.1 \mathrm{mg}$ of Pronase (Calbiochem 53702) assayed at $\mathrm{pH} 9.5$.

The midgut fluids exhibit low activity toward amylose, suggesting a limited capacity to digest starch. No activity could be detected toward cellulose, carboxymethylcellulose, xylan, locust bean gum, pectin, or laminarin. These species appear poorly equipped to exploit the energy and carbon content of the structural polysaccharides of plant tissue.

Nutritional indices. A. pometaria has a higher relative growth rate (RGR) than $A$. senatoria on every species of oak foliage except for red oak (Table 4). Likewise, relative nitrogen accumulation rate
(RNAR), which is the growth rate expressed in terms of nitrogen accumulation, is uniformly higher in the early-season feeder. The relative consumption rate ( $\mathrm{RCR}$ ) of $A$. pometaria is uniformly higher than that of $A$. senatoria, and since the nitrogen content of young foliage is higher than that of mature foliage, the relative nitrogen consumption rate (RNCR) is also higher for $A$. pometaria than for A. senatoria. In most cases values for the efficiency of conversion of ingested biomass into insect biomass ( $E C I$ ) do not differ significantly between the two species when they are grown on foliage from the same species of oak. Thus, the higher relative growth rate of $A$. pometaria is a consequence of a greater consumption rate, not to greater efficiency in using ingested material for growth. On the other hand, nitrogen utilization efficiency (NUE or ECI $(\mathrm{N})$ ) is significantly higher for A. senatoria than for $A$. pometaria on bur and red oak foliage.

The equality of the values for ECI for the two species fed the same species of oak foliage is not due to the equality of the values for AD and E.CD, which are the components of $\mathrm{ECI}$, but rather to compensatory differences in the values of these two indices. AD is uniformly higher and ECD uniformly lower for $A$, pometaria. Indeed, it seems quite fortuitous that the values for ECI are equal for the two species. The higher values of ECD for $A$. senatoria than for A. pometaria are noteworthy, since the mature foliage consumed by the former species has a lower water content than the young foliage consumed by $A$. pometaria. In other studies, low water content in foliage generally results in a reduction of ECD and a corresponding reduction in ECI and RGR (Scriber, 1977, 1979).

A. pometaria and A. senatoria respond very differently to differences in the quality of the foliage of

Table 3. Enzymatic activity of midgut homogenates from $A$. pometuria and $A$, senatoria. $V$ alues are $\bar{X} \pm S E$ with the number af $s e p a r a t e$ extracts assayed in parenthesis. One unit of amylase activity is the amount of enzyme required to liberate one micromole of maltose equivalents per minute. One unit of protease activity is the amount of enzy me required to bring about a change in absorbance at 520 nm of 0.001 absorbance units per minute.

\begin{tabular}{|c|c|c|c|c|}
\hline Species & $\mathrm{T}\left({ }^{\circ} \mathrm{C}\right)$ & $\mathrm{pH}$ & $\begin{array}{l}\text { Amylase activity } \\
\text { (Units } \times 10^{3} / \mathrm{mg} \text { dry wt) }\end{array}$ & $\begin{array}{l}\text { Ptotease activity } \\
\text { (Units/mg dry wt) }\end{array}$ \\
\hline \multirow[t]{2}{*}{ A. pometaria } & $37^{\circ}$ & 9.5 & $17.8 \pm 1.7$ & - \\
\hline & $37^{\circ}$ & 10.5 & - & $498 \pm 38(3)$ \\
\hline \multirow[t]{2}{*}{ A senatorta } & $37^{\circ}$ & 9.5 & $8.0=0.3(5)$ & - \\
\hline & $37^{\circ}$ & 10.5 & - & $569 \pm 56(3)$ \\
\hline
\end{tabular}


Table 4. Nutritional indices of $A$, pometaria larvae on early-season aak foliage and $A$. senatora larvat on late-season oak foliage. Values are $\bar{X} \pm S E$. Data on late-season foliage are from Lawsonet al.(1982). Mean values followed by different letters differ significantly $(p<0,05)$ from other values in the same column.

\begin{tabular}{|c|c|c|c|c|c|c|c|c|}
\hline & $\begin{array}{l}\text { RGR } \\
(\mathrm{mg} / \mathrm{mg} / \mathrm{d})\end{array}$ & $\begin{array}{l}\mathrm{RCR} \\
(\mathrm{mg} / \mathrm{mg} / \mathrm{d})\end{array}$ & $\begin{array}{l}\mathrm{ECI} \\
(\%)\end{array}$ & $\begin{array}{l}\mathrm{AD} \\
(9)\end{array}$ & $\begin{array}{l}\mathrm{ECD} \\
(\%)\end{array}$ & $\begin{array}{l}\text { RNAR } \\
(\mu \mathrm{g} / \mathrm{mg} / \mathrm{d})\end{array}$ & $\begin{array}{l}\text { RNCR } \\
(\mu \mathrm{g} / \mathrm{mg} / \mathrm{d})\end{array}$ & $\begin{array}{l}\text { NUE } \\
(\%)\end{array}$ \\
\hline \multicolumn{9}{|l|}{ Alsophila pometaria } \\
\hline \multirow[t]{2}{*}{ White oak } & $0.330^{\mathrm{c} d \mathrm{~d} e}$ & $3.34 \mathrm{e}$ & $9,9^{\mathrm{b}, \mathrm{c}}$ & $53.7^{\prime}$ & $18.9 \mathrm{a}$ & $31.4^{d .2}$ & $101.4^{b, c}$ & $31.1^{a}$ \\
\hline & \pm 0.009 & \pm 0.11 & \pm 0.3 & \pm 2.5 & $\neq 1.3$ & \pm 1.0 & \pm 3.4 & \pm 1.1 \\
\hline \multirow[t]{2}{*}{ Swamp-white oak } & $0.358^{\mathrm{d}, \mathrm{e}}$ & $2.98 \mathrm{c}, \mathrm{i}$ & $12.3 d, c$ & $47,9: .8$ & $26.6^{a} \cdot b$ & $35.7^{r}$ & $108.0^{e}$ & $33.6^{a . b}$ \\
\hline & \pm 0.013 & \pm 0.21 & \pm 0.7 & \pm 2.3 & \pm 3.0 & \pm 1.8 & \pm 7.7 & \pm 1.6 \\
\hline \multirow[t]{2}{*}{ Bur oak } & $0.368 \mathrm{e}$ & $2.85 \mathrm{c}, \mathrm{d} . \mathrm{s}$ & $12.9 \mathrm{c}$ & $49.1^{e, f}$ & $27.1^{\mathrm{a}, \mathrm{b}}$ & $33.7^{\mathrm{e}}$ & $96.7^{h, c}$ & $34.8^{\mathrm{a}, \mathrm{b}}$ \\
\hline & \pm 0.014 & \pm 0.09 & \pm 0.3 & \pm 2.3 & \pm 2.0 & \pm 1.6 & \pm 4.4 & \pm 10 \\
\hline \multirow[t]{2}{*}{ Red oak } & $0.285^{b, c, d t}$ & $2.90 \mathrm{cdce}$ & 10.]^{b}=$ & $41.9 \mathrm{~d}, \mathrm{e}$ & $29.4 \mathrm{a}, \mathrm{b} ; \mathrm{c}$ & $28.8^{\mathrm{d}}$ & $85.5^{b}$ & $34.7^{\mathrm{a}, \mathrm{b}}$ \\
\hline & \pm 0.023 & +0.28 & \pm 0.6 & \pm 4.2 & \pm 6.7 & \pm 0.9 & $\pm \quad 5.8$ & \pm 2.1 \\
\hline \multirow[t]{2}{*}{ Black oak } & $0.3280,4, c$ & $3.08 \mathrm{~d} . \mathrm{e}$ & $10.7^{b c}$ & 38.8 cote & $28.2^{\mathrm{A}, \mathrm{k}}$ & $30.3^{d, e}$ & $88.1^{\circ}$ & $34,4, b$ \\
\hline & \pm 0.011 & \pm 0.09 & \pm 0.4 & \pm 2.0 & \pm 1.8 & \pm 1.5 & \pm 2.6 & \pm 5.2 \\
\hline \multicolumn{9}{|l|}{ Anisota senatoria } \\
\hline \multirow[t]{2}{*}{ White oak } & $0.245^{a, b}$ & $2.48 \mathrm{~b} \cdot \mathrm{c}$ & $9.9 \mathrm{~b}, \mathrm{e}$ & $27.0^{\mathrm{b}}$ & $36.8^{\mathrm{b}, \mathrm{c}}$ & $19.9 \mathrm{~b}$ & $56.0^{\mathrm{a}}$ & $35.5^{\mathrm{a}, \mathrm{h}}$ \\
\hline & \pm 0.006 & +0.05 & \pm 0.2 & \pm 0.5 & \pm 0.9 & \pm 0.6 & $=1,1$ & \pm 1.0 \\
\hline \multirow[t]{2}{*}{ Swamp-white oak } & $0.273 b . c$ & $2.15^{\mathrm{a}, \mathrm{b}}$ & $12.7 \%$ & 31.130 & $41.0^{h, c}$ & $23.9 \mathrm{c}$ & $60.8^{\mathrm{a}}$ & $39.4 b$ \\
\hline & \pm 0.004 & \pm 0.03 & \pm 0.2 & \pm 0.5 & +0.9 & \pm 0.4 & \pm 0.9 & \pm 0.6 \\
\hline \multirow[t]{2}{*}{ But oak } & $0.272^{b_{r}, e}$ & $1.94^{n}$ & $14.2^{\mathrm{f}}$ & $32.7 b, c, d$ & $46.3 \mathrm{c}$ & $24.8^{\circ}$ & $56.8^{a}$ & 44.38 \\
\hline & \pm 0.004 & \pm 0.06 & $=0.4$ & \pm 1.8 & \pm 3.2 & \pm 0.4 & $\pm \quad 1.9$ & \pm 1.3 \\
\hline \multirow[t]{2}{*}{ Pin oak } & $0.276^{\mathrm{b} .}$ & $2.43^{b, C}$ & $11.3^{\mathrm{c} d}$ & $31.4^{\mathrm{b} . \mathrm{F}}$ & $36.6^{\mathrm{b} . \mathrm{c}}$ & $24.0^{c}$ & $55.2^{\mathrm{a}}$ & $43.5=$ \\
\hline & \pm 0.008 & \pm 0.04 & \pm 0.3 & \pm 0.8 & \pm 1.3 & \pm 0.7 & \pm 0.8 & \pm 1.1 \\
\hline \multirow[t]{2}{*}{ Red oak } & $0.277^{\mathrm{b}, \mathrm{c}}$ & $2.63 \mathrm{~cd}$ & $10.5^{b, c}$ & $26.1 \mathrm{~b}$ & $41.2^{b . e}$ & $26.0^{\circ}$ & $58.6^{a}$ & $44.5^{\circ}$ \\
\hline & \pm 0.011 & $\pm 0,06$ & \pm 0.4 & +0.8 & \pm 2.4 & \pm 1.1 & \pm 14 & \pm 1.9 \\
\hline \multirow[t]{2}{*}{ Black-oak } & $0.196^{\mathrm{a}}$ & $2.44^{b, c}$ & $8.1^{\circ}$ & $18.1^{a}$ & $46.4=$ & $176^{2}$ & $51.5^{\mathrm{a}}$ & $34.6^{9,6}$ \\
\hline & \pm 0.006 & 10.05 & s 0.3 & \pm 0.6 & \pm 0.3 & \pm 0.6 & \pm 1.0 & \pm 1.4 \\
\hline
\end{tabular}

the various oak species fed to them (Table 5, Fig. 2). For A. pometaria, RGR and ECI correlate withleaf nitrogen content. Since the larvae consume oak foliage with different nitrogen levels at the same rate, but use the high-nitrogen leaves somewhat more efficiently for growth, growth is naturally faster on high-nitrogen foliage. The positive corre-

Table 5. Correlation coefficients of nutritional indices of larval growth of $A$. pometaria and $A$. senatoria on leaf nitrogen content $\left({ }^{*} \mathrm{p}<0.05,{ }^{* *} \mathrm{p}<0.01\right)$.

\begin{tabular}{lcc}
\hline Index & $\begin{array}{l}\text { A. pumetaria } \\
\mathrm{n}=5\end{array}$ & $\begin{array}{l}\text { A. senaloria } \\
n=6\end{array}$ \\
\hline RGR & $0.82^{*}$ & 0.51 \\
RCR & -0.30 & $-0.92^{* *}$ \\
ECI & $0.85^{*}$ & $0.92^{* *}$ \\
AD & 0.50 & $0.72^{*}$ \\
ECD & -0.05 & 0.30 \\
RNAR & $0.91^{*}$ & 0.49 \\
RNCR & $0.81^{*}$ & 0.60 \\
NUE & 0.30 & 0.37 \\
\hline
\end{tabular}

lation of ECI with nitrogen content oceurs in spite of the absence of any correlation of either AD or ECD with leaf nitrogen. In A. senatoria, RCR is negatively correlated with leaf nitrogen, as the larvae consume low-nitrogen leaves at a faster rate than high-nitrogen leaves. However, larval ECI and $A D$ are positively correlated with leaf nitrogen. As a result, growth rates are approximately the same on the different species of oak foliage, and in any event are not correlated with leaf nitrogen.

Uniform consumption rates by $A$. pometaria on leaves that vary in nitrogen concentration result in values of RNCR which are positively correlated with leaf nitrogen. Since larval nitrogen utilization efficiency, NUE, is fairly constant on the different oak species, RNAR correlates positively with leaf nitrogen. By contrast in $A$. senatoria, an increased consumption rate on leaves low in nitrogen results in uniform values for $R N C R$, and since $N U E$ is also independent of leaf nitrogen, RNAR is also about the same on most species of oak and is not correlated with leaf nitrogen. 

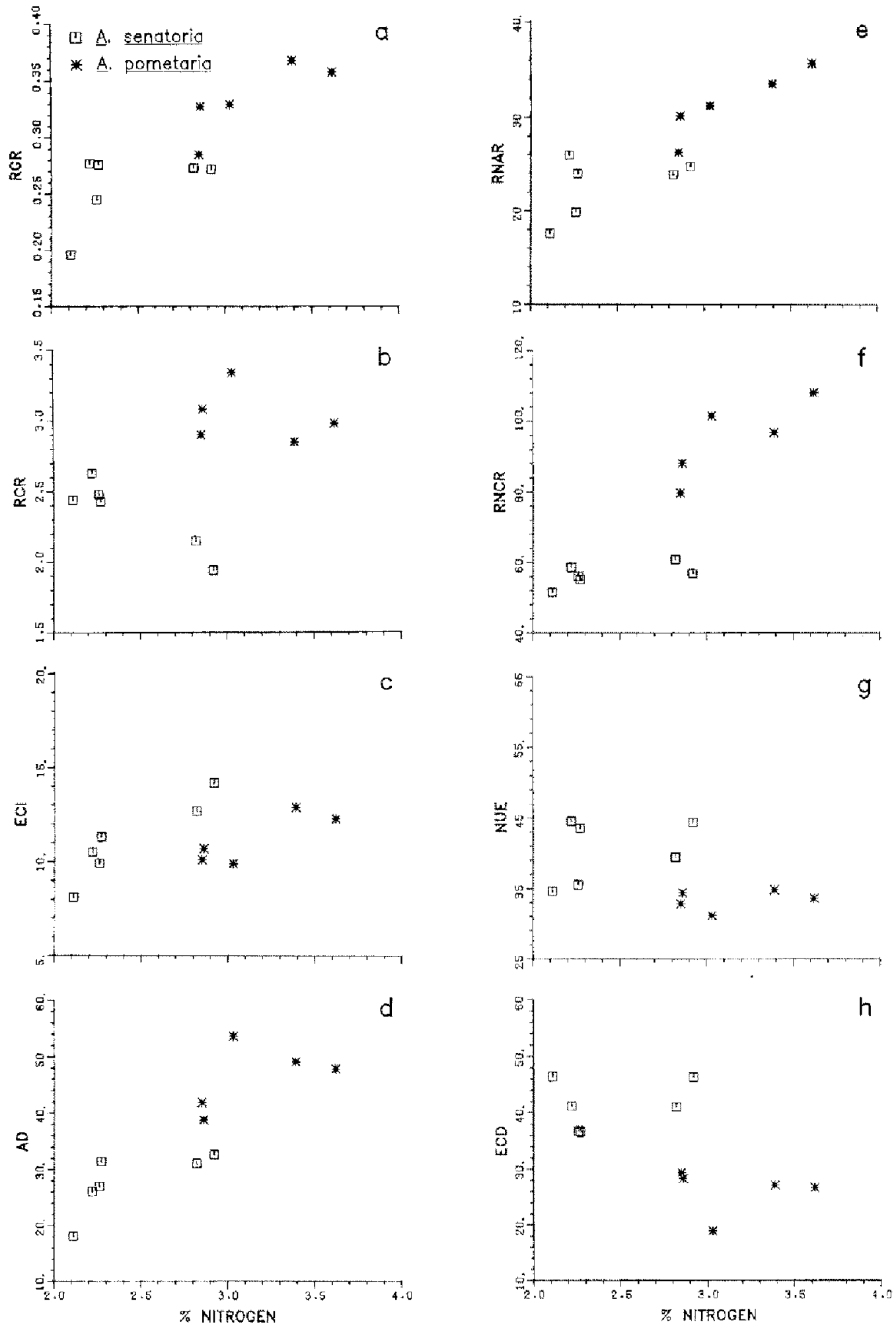

Fig. 2. Relationship between leat nitrogen concentration and larval RGR (a). RCR (b), ECl(c), AD (d), RNAR (e), RNCR (f), NUE (g), and $\mathrm{ECO}$ (h). 
There were no correlations between any of the nutritional indices for either species with total phenolic content, proanthocyanidin content or protein-precipitating capacity of the foliage.

\section{Discussion}

Herbivores that feed upon forb foliage or the young foliage of trees generally have higher growth rates than herbivores that consume the mature foliage of trees (Feeny, 1975; Scriber \& Feeny, 1979; Scriber \& Slansky, 1981). This is usually attributed to a combination of differences in consumption rates and differences in the quantity and quality of the protein present in the foliage. Herbivores that feed upon forb foliage or the young foliage of trees typically have higher relative consumption rates than species that feed upon mid-or late-season tree foliage (Scriber \& Feeny, 1979; Scriber \& Slansky, 1981). Since young foliage contains higher levels of nitrogen, early-season feeders naturally consume this critical element at rates considerably greater than late-season feeders. Furthermore, it is generally assumed that late-season tree foliage not only contains lesser amounts of readily digestible soluble metabolic protein, but also that the digestibility of the protein that is present is reduced by elevated levels of tannins and other polyphenols. Thus, it is presumed that reduced digestibility (AD) of mature foliage will result in reduced efficiency of conversion of ingested food (ECI), and this in turn will contribute to lower growth rate for late-season herbivores on nitrogen-poor diets. Although the results of this study agree in part with this general interpretation of differences between the nutritional ecology of early-and late-season herbivores, they are also at variance with this interpretation in a few important and interesting ways.

As anticipated, A. pometaria, the early-season feeder, has a significantly higher relative growth rate (RGR) and relative consumption rate (RCR) than $A$. senatoria, the late-season feeder. Also, as expected, the young oak foliage is higher in nitrogen than the mature foliage, and the approximate digestibility (AD) of young foliage by $A$. pometaria is higher than that of mature foliage by $A$. senatoria. However, contrary to expectations, the higher value for the AD of young foliage by $A$. pometaria does not translate into a higher value for $\mathrm{ECI}$.
Owing to the low values of $\mathrm{ECD}, \mathrm{ECI}$ values are no different from those of $A$. senatoria on mature oak foliage. In fact, nitrogen is actually assimilated more efficiently by $A$. senatoria than by $A$. pometaria on two of the oak species. Thus, the higher relative growth rate of the early-season feeder in this study is due entirely to a higher consumption rate.

Leaf nitrogen is a major determinant of nutrient quality for many insects, including Lepidopteran larvae (Slansky \& Feeny, 1977; McNeill \& Southwood, 1978; Mattson, 1980). The influence of leaf nitrogen content on the various nutritional indices not only emphasizes the importance of this critical element in the nutritional ecology of the two species examined in this study, but also reveals interesting differences in the feeding strategies of the early-season $v i s$ à vis the late-season feeder. A. pometaria consumes all foliage at roughly the same rate and grows at a rate directly related to leaf nitrogen concentration. By contrast, $A$. senatoria increases its consumption rate in response to decreased leaf nitrogen content and grows at approximately equal rates on most leaf species.

Although the spring foliage had lower levels of proanthocyanidins than the mature foliage, total phenols and total tannins (as measured by proteinbinding capacity) were as high or higher in the young foliage than in the mature foliage. It has been proposed that tannins act as dose-dependent inhibitors of herbivore digestion (Feeny, 1976; Rhoades \& Cates, 1976). However, in this study there was no significant correlation between leaf tannin concentration, as measured by total phenolic content, proanthocyanidin content, or protein-precipitating capacity (Martin \& Martin, 1982), and the AD's, ECI's or NUE's of either caterpillar species. Thus, this study fails to provide any support for the suggestion that tannins are effective, all-purpose, dosedependent inhibitors of digestion and assimilation. Other studies by Fox \& Macauley (1977), Bernays (1981), Rausher (1981) and Lawson et al. (1982) have also failed to provide evidence that tannins reduce the nutrient quality of foliage to an herbivore. We suggest that the main benefit of spring feeding is the availability of succulent, nitrogenrich foliage, and not the avoidance of high tannin levels.

The digestive systems of the two insects are very similar biochemically, and appear to be well-de- 
signed for effective protein digestion. There is no indication that the late-season feeder is somehow better adapted biochemically for the utilization of high-tannin, low-nitrogen foliage.

The difference in feeding behavior of the two species would seem to reflect commitments to two very different strategies of resource utilization. The low consumption rate of $A$. senatoria can be viewed as a mechanism to maximize protein digestion, since it will result in longer gut residence times during which the foliar protein is in contact with the powerful proteolytic enzymes of the digestive juices. On the other hand, the high consumption rate of A. pometaria can be interpreted as a mechanism for achieving a high growth rate on the nitrogenrich spring foliage, albeit at the expense of efficiency. An adequate digestive efficiency is maintained despite the short gut residence time by the high proteolytic activity of the gut fluids. Thus, in common with the larvae of Pieris rapae on nitrogen-rich crucifer foliage (Slansky \& Feeny, 1977), the spring feeder appears to have a feeding strategy that favors rate over efficiency, while the late summer feeder has a strategy that favors efficiency over rate.

\section{Acknowledgements}

This research was supported in part by the Michigan State Experimental Station and in part by grants from the National Science Foundation to RWM (DEB78-111435 and DEB80-22634) and M M M (PCM78-22733). We thank G. J. Grafius, M. J. Klug and J. R. Miller for critical reviews of an early version of the manuscript, and $W$. H. Taft, Jr. and G. Walker for technical assistance.

\section{Résumé}

Ecologie alimentaire de chenilles d'Alsophila pometaria et d'Anosita senatoria consommant du feuillage précoce ou tardif de chêne

Alimentées sur feuillage jeune de chêne, les chenilles d'Alsophila pometaria avaient un taux relatif de croissance ( $R G R$ ) et un taux relatif d'accumulation d'azote (RNAR) plus élevés que les chenilles d'Anisota senatoria alimentees sur feuillage mûr de chêne. Bien que le jeune feuillage soit plus efficace- ment digéré par A. pometaria (AD plus élevé), il n'est pas assimilé et utilisé pour Ja croissance avec de meilleurs rendements (les ECI ne sont pas différents). Ainsi le taux de croissance plus élevé d' $A$. pometaria est dî entièrement à un taux de consommation plus important (RCR et RNCR). Le feuillage jeune est significativement plus riche en azote et en eau que le feuillage mur, thais les niveaux de phénol et de tanins sont les mêmes. $A$ pometaria consomme les feuilles de différentes espèces de chênes au même taux, indẻpendamment de la teneur en azote, tandis que $A$. senazoria accroit sa consommation en réponse à une diminution de la teneur en azote. 11 en résulte que le taux de croissance d'A. pometaria dépend directement de la teneur en azote des feuilles, tandis que celui d' $A$. senatoria en est indépendant. Les systèmes digestifs des deux insectes sont biochimiquement semblables et sont efficaces pour la digestion des proteines. Les tanins et les phénols n'influent pas sur les indices nutritionnels de ces deux especes. Nous estimons que le principal intérêt de l'alimentation printanière est la disponibilité en feuillage succulent, riche en azote, et non l'absence de feuilles à haute teneur en tanin. L'alimentation printanière semble correspondre à une strategie alimentaire qui favorise la croissance aux dépens de l'efficacité tandis que l'alimentation en fin d'été est une stratégie qui favorise l'efficacité sur la rapidité.

\section{References}

Becker. P. \& J. S. Martin, 1982. Proten-bunding capacitıes of tannins in Shorea (Dipterocarpacede) seedling leaves. J. Chem. Ecol. 8: 1353-1367.

Betnays, 2 , A. 1981. Plant tannins and insect herbivores: an appraisal. Ecol. Entomol. 6: 353-360.

Bernfeld, P., 1955. Amylases, $\alpha$ - and $\beta$ - In S. P. Colowiek \& N. O Kaplan (eds.), Methods of Enzymology, vol. 1. New York, Academic Press: 149-150.

Coley, P. D., 1980. Etfect of leaf age and plant life history patter ns on herbivory. Nature 284: $\$ 45-546$,

Feeny, P. 1968. Efect of leaf tannins on larval growth of the winter moth Operophthera brumara. J. Inșect Physiol. 14: $805-817$.

Feeny. P., 1970. Seasonal changes in oak leaf tannins and nutrients as a cause of spring feeding by winter moth caterpillars. Ecology 51: 565-581.

Feeny, P. 1975. Biochemical coevolution between plants and their insect herbivores. In L. E. Gibert \& P. H, Raven (eds), Coevolution of Anmak mi Plants. Ausin, University of Texas Press: 3.19 
Feeny, P., 1976. Plant apparency and chemical defense. Rec. Adv. Phytochem. 10: 1-40.

Fox, L. R. \& B. J. Macauley, 1977. Insect grazing on Eucalyptus in response to variation in leaf tannins and nitrogen. Oecologia 29: $145-162$.

Gartlan, J. S., D. B. McKey, P. G. Waterman, C. N. Mbi \& T. T. Struhsaker, 1980. A comparative study of the phytochemistry of two Aftican rain forests. Biochem. Syst. Ecol. 8: $401-422$.

Govindarajan, V. S. \& A. G. Mathew, 1965. Anthocyanidins from leucoanthocyanidins. Phytochemistry 4: 985-988.

Haukioja, E., P. Niemela. L. lso-Iivarı, H. Ojala \& E. M. Aro, 1978. Birch leaves as a resource for herbivores. I. Variation in the suitability of leaves. Rep. Kevo Subarctic Res. Stat. 14: $5-12$.

Hillis, W. E. \& T. Swain, 1959. The phenolic constituents of Prunts domestica. Il. The analysis of tissues of the Victoria plum tree. J. Sci. Fd. Agric. 10: I35-144.

Hough, J. A.\& D. Pimentel, 1978. Influence of host foliage on development survival, and fecundity of the gypsy moth. Environ. Entomol. 7; 97102.

Lawson, D. L., R. W. Merrill, M. J. Klug \& J. S. Martin, 1982. Utilization of late season foliage by the orange striped oakworm, Anisofa senatoria (J. E Smith) (Citheroniidae). Ent. exp. appl. 32: 242-248.

Mansingh, A., 1972. Developmental rcsponse of Antheraea pernai to seasonal changes in oak leaves from two localities. J. Insect Physiol. 18: 1395-1401.

Martin, M. M., J. J. Kukor, J. S. Martin, D. I.. Lawson \& R. W. Merritt, 1981a. Digestive enzymes of larvae of three spectes of caddisflies (Trichoptera). Insect Biochem. 11: 501-505.

Martin, M. M., J. J. Kukor, J.S. Martin, T. E. O'Toole \& M. W. Iohnson, 198 Ib. Digestive enzymes of fungus-fecding beetles. Physiol. Zool. 54: 137. I45.

Martin, J.S. \& M. M. Martin, 1982. Tannın assays in ecological studies: lack of correlation between phenolics, proanthocyanidins and protein-binding constituents in mature foliage of six oak species. Oecologia 54: $205-211$.

Matson, W. J., 1980. Herbivory in relation to plant nitrogen content. Ann. Rev. Ecol. Syst. 11:119-161.

MeNcill, S. \& T. R. E. Southwood, 1978. The role of nitrogen in the development of insect/host plant relationships. In J. Harborne (ed.). Biochemical Aspects of Plant and Animal Coevolutum. I ondon, Academic Press: 77-98.
Mitter, C., D. J. Futuyma, J. C. Schnelder \& J. D. Hare, 1979. Genetic variation and host plant relations in a parthenogenetic moth. Evolution 33: $777-790$

Oates, J. F., P. G. Waterman \& G. M. Choo, 1980. Food selcction by the South Indian lcaf-monkey, Presbytis johnii, in relation to leaf chenustry. Oecologia 45: 45 56.

Rausher, M. D., 1981. Host plant selection by Battus philenor butterflies: the roles of predation, nutrition, and plant chemistry. Ecol. Monogr. 51: 1-20.

Rhoades, D. F. \& R. G. Cates, 1976. Toward a general theory of plant and antiherbivore chemistry. Rec. Adv. Phytochem. 10: 168213 .

Ribéreau-Gayon, P.. 1968. Plant Phenolics. Edinburgh. Oliver and Boyd.

Sehultz, J. C.. P. J. Nothnagle \& I. T. Bald win. 1982. Seasonal and individual varation in leaf quality of two northern hardwood tree species. Am. J. Bot. 69: 753-759.

Schweitzer, D. F., 1979. Effects of foliage age on body weight and survival in larvae of tribe Lithophanini (Lepidoptera: Noctuidae). Oikos 32: 403-408.

Scriber, J. M., 1977. Limiting effects of low leaf-water content on the nitrogen utilization, energy budget, and larval growth of Hyalophora cecropia (Lepidoptera: Saturniidae). Oecologia 28: $269-287$.

Scriber, J. M., 1979. Effects of leaf-water supplementation upon post-ingestive nutritional indices of forb-, shrub-, wine-, and tree-feeding Lepidoptera. Ent. exp. appl. 25: 240-252.

Scriber, J. M. \& P. Feeney, 1979. Growth of herbivorous caterpillars in relation to feeding specialization and to the growth form of their food plants Ecology 60: 829850 .

Scriber, J. M. \& F. Slansky, Jr, 1981. The nutritional ecology of immature insects. Ann. Rev. Entomal. 26: 183-211.

Slansky, F. Jr. \& P. Feeny, 1977. Stabilization of the rate of nitrogen accumulation by larvae of the cabbage butterfly on wild and cultivated food plants. Ecol. Monogr. 47: 209-228.

Sokal, R. R. \& F. J. Rohlf, 1969. Biometry. San Francisco, W. H. Freeman.

Swain, T. \& W. E. Hillis, 1959. The phenolic constituents of Prumus domestica. I. The quantitative analysis of phenolic constituents. J. Sci. Fd. Agric. 10: 63-68.

Waldbauer, G, 1968. The consumption and utilization of food by insects. Adv. Insect Physiol. 5: 229-288.

Accepted: December 29, 1983. 